\title{
Support of State and Private Institutions for Biomedical Start-ups in Russia
}

\section{Olga Guseva}

$\mathrm{PhD}$ student

ORCID

E-mail: oguseva@hse.ru

Doctoral School of Economics, National Research University Higher School of Economics,

Moscow, Russia

Journal of Corporate Finance Research, Vol. 15, No. 2, pp. 27-41 (2021)

For citation: Guseva, O. (2021) «Support of State and Private Institutions for Biomedical Start-ups in Russia», Journal of Corporate Finance Research / Корпоративные Финансы | ISSN: 2073-0438, 15(2), cc. 27-41. doi: 10.17323/j.jcfr.20730438.15.2.2021.27-41.

Received 8 January 2021 | Peer-reviewed 18 January 2021 | Accepted 19 January 2021 


\section{Abstract}

This paper describes the differences between biomedical start-ups with state support and start-ups with support provided by private market participants in Russia as a country with limited private investments. Based on the sample of Skolkovo biomedical start-ups, we analyse ownership and management characteristics of start-ups as well as the performance of companies supported by these two types of institutions.

To compare start-ups supported from different sources, the sample of biomedical companies is divided into four clusters based on the presence of state and/or private support. The results of cluster characterization indicate that start-ups with different types of support vary significantly in ownership concentration, share of managerial ownership, gender diversity and CEO experience.

Although tests for differences among the groups' mean values showed the insignificance of performance variation among clusters, start-ups with private funding in the sample were mostly smaller-sized companies with fewer patents and employees. At the same time, start-ups that were supported from both private and state sources performed better on average in the number of employees and patents and the presence of revenue. Although the causal relationship between the type of support and start-up performance is not investigated in this paper, our results suggest the importance of the synergy of state and private support for biomedical start-up performance in Russia.

Besides contributing to the literature on start-up support in emerging markets, this paper is, as far as we know, one of the first academic studies to provide insights into the market of Russian biotech start-ups.

Key words: biotech start-ups, state support, emerging markets

\section{Introduction}

After its outbreak in Q1 2020, the coronavirus pandemic resulted in a world crisis with an unprecedent decline in trade activity and petroleum demand, leading to an overall forecast of $-4.9 \%$ for global GDP growth in 2020 [1]. Nevertheless, some industries managed to win out in the crisis and attract investors' attention: the S\&P 500 pharmaceuticals, biotech and life sciences index significantly outperformed the market S\&P 500 index [2]. In Russia, the pharmaceutical market grew by $23 \%$ in monetary terms during Q1 2020 year-over-year [3], while Russian companies in pharma and medical equipment manufacturing were the only market participants to increase their output in April and May year-over-year [4].

However, the biotechnology sector in general and biotech start-ups in particular had not been popular among institutional and private investors in Russia historically. In 2018, venture investments in biotech represented only around $4 \%$ of total venture investments in Russia (just as in Asia with its majority of developing countries), while such investments were much more common in the US (Figure 1).

Biotechnology companies face significant challenges in securing investments in comparison to other industries, as innovations in this field require not only collaborations between scientists and businessmen [7] but also a lot more time for product development, necessitating longer-term capital investments. The challenge for small businesses is even greater on account of their higher opacity. Small businesses are also more vulnerable to crises: for example, after the 2008 crisis, it took two years more for smaller companies to return to their pre-crisis contribution to the GDP in comparison to larger enterprises [8].
Figure 1. Share of venture investments by sector in 2018

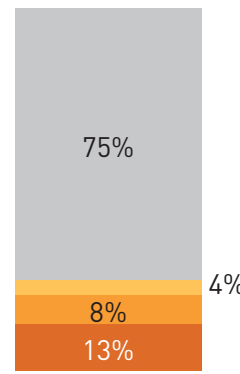

Russia

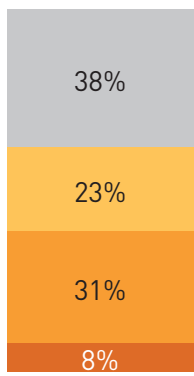

USA

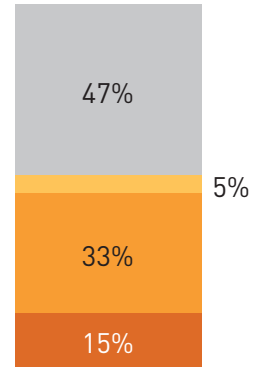

Asia
Other Industry Biotech $\square$ IT

Source: author's representation based on $[5 ; 6]$.

The specificity and vulnerability of small biotech firms explain the importance of state support for such companies, especially on emerging markets with institutional voids. In both developed and developing countries, states recognize the need for supporting small and medium enterprises (SMEs), as entrepreneurship and the entrepreneurial ecosystem have been identified as drivers of national economic growth and job creation [9-11]. Moreover, special attention has been paid to new technology-based firms, whose products and innovations can create enormous economic value and have an impact on everyone's life [12].

The most typical forms of state support for SMEs usually include custom and tax exemptions and loans on preferential terms. Such measures are implemented by states both on emerged markets (e.g. Start Up Loans programme in the UK, Small Business Innovation Research (SBIR) programme in the USA) and in emerging countries (e.g. Small Business Innovation Research Initiative in India, SME bank programmes in Malaysia). 
However, this paper shall rather focus on the specific type of state support for new technological ventures. This type of support, which includes establishing and funding different varieties of state technoparks, incubators and accelerators, is more often seen in countries with significant state participation in the economy (e.g. Sweden, China, or Israel). We shall specifically focus on start-ups in Russia, as the Russian venture market is characterized by the presence of significant state financing as well as limited access to private capital financing. Indeed, the total volume of venture capital investments on the Russian market amounted to less than $0.1 \%$ of the volume of global venture capital investments in 2018. At the same time, in 2018 Russian tech companies received almost $\$ 99$ million from state institutions, or $13 \%$ of the total venture capital investments in Russia, according to Dsight [13].

The main aim of this paper is to describe the differences between biotech start-ups with state support provided by development institutes and start-ups with support provided by professional market participants such as private equity and venture funds, business angels and private companies in Russia as a country with limited private investments. In particular, we shall focus on two research questions: first of all, we shall analyse whether the ownership and management characteristics of start-ups with support from state or private institutes are heterogeneous. Second, we shall consider whether the performance of start-ups supported by these two types of institutions differs.

In this paper we shall also take a closer look at 510 Russian biotech start-ups using a sample of resident companies of the Skolkovo innovation system, the largest Russian innovation ecosystem. However, the type of support provided to these start-ups differs significantly: while some of the companies are supported only by private investors, other firms receive grants from the Skolkovo Foundation and/or become residents of technoparks. For the purpose of this study, we consider a sample of 213 start-ups for which the forms of support provided by investors can be traced from the information presented on the Skolkovo platform, with data about ownership structure and management characteristics collected from the Spark Interfax Database.

After cluster characterization, we shall show that start-ups supported by the state and start-ups that receive support from private investors differ significantly in ownership concentration, share of managerial ownership, gender diversity and CEO experience.

Although tests for differences between the groups' mean values confirmed the insignificance of performance variations among groups, the cluster of start-ups with private funding in our sample includes smaller-sized companies with fewer patents and employees in comparison to companies in clusters with state or mixed support. Start-ups that were supported by both private and state sources performed better on average in the number of employees and patents and the presence of revenue. Such results can be an indicator of the life-cycle differences of start-ups: while the support of private institutions is more often observed among companies without any revenue, state institutions tend to focus on more mature companies.

\section{Literature review}

Before analysing the different kinds of support, we should note that the sample is biased, as all of the start-ups in it participate in the Skolkovo innovation system, and 311 of them (61\% of the final sample) are registered in Skolkovo. A spatial concentration of start-ups can generate strong cross-company spillovers that are observed in many areas of concentration of firms around the world (e.g. New York, Boston or Shanghai), while cluster support policies exist in many developed and developing countries (e.g. special economic zones in China or regional innovative clusters in Sweden). Therefore, to generalize our conclusions based on the Skolkovo sample to Russian start-ups outside Skolkovo, additional tests must be performed. This lies outside the scope of the present paper, however.

In this study, we shall focus only on start-ups in the biomedical cluster, the industry with the most significant emerging technologies today [14]. Most start-ups from the research-intensive biotech industry require not only financial support but also special infrastructure; as a result, membership in a technopark that provides the necessary equipment for research plays a very important role for biomedical start-ups. In addition, owning a patent is a major indicator of success of biotech start-ups, and we are able to trace this indicator using the available data.

\section{Characteristics of start-ups supported by state and private institutions}

The academic literature presents significant evidence that the individual characteristics of entrepreneurs have an influence on their choice of financing. Using a purely theoretical approach, Schwienbacher [15] showed that the type of entrepreneur (life-style, serial or pure profit-maximizing entrepreneur) affects the choice of financing, including its source. Drover, Wood and Fassin [16] confirmed that entrepreneurs with a high fear of failure are less likely to partner with unethical investors.

Therefore, different types of entrepreneurs and companies can show different preferences when choosing between state and private types of support. Still, as Islam, Fermeth and Marcus [17] showed, these sources are not mutually exclusive: on the contrary, US state research grants are used by start-ups as signals to advance relationships with VCs, as start-ups which win prestigious state grants are $12 \%$ more likely to get $\mathrm{VC}$ funding subsequently.

At the same time, not only entrepreneurs choose their sources of funding: state and private institutions also select investments in line with their goals and preferences.

There exists extensive academic research on the process of investment selection by private institutions. Knockaert, Clarysse and Wright [18] identified three clusters of venture fund investors based on an analysis of their investment decisions: technology (investors whose decision is primarily based on the technology involved), people (investors who attach importance to the personal qualities of the team) and financial (investors who make their decision based on ROI, growth and team competences). Malmstrom, Voit- 
kane, Johansson and Wincent [19] showed that women who signal entrepreneurial attitude receive significantly less capital when applying for venture capital funding.

Although state institutions are more often perceived as entities whose decisions can be influenced by personal ties, Shane and Cable [20] confirmed that social relationships play a role in the investment selection process of venture funds, too.

While private institutions are interested in the wealth-maximization of particular shareholders, the purpose of state institutions is the maximization of state welfare. Afful-Dadzie and Afful-Dadzie [21] analysed criteria for the selection of businesses by state venture funds from a vast body of academic literature and showed that, along with standard venture fund criteria such as entrepreneur/team personality and experience, product potential, and the financial and market characteristics of the product, an important factor for state institutions is the product's societal contribution. Uzuegbunam, Liao, Pittaway and Jolle [22] further investigated the selection criteria of state venture funds, showing that the education of the founder is more relevant than his or her experience, while the number of patents owned by the company positively influences investment in such firms.

\section{Performance of start-ups supported by state and private institutions}

The positive impact of private investments on start-up performance is well documented in academic literature. However, most of the research in this field is devoted to the importance of venture fund support. Using a sample of US medical start-ups, Pahnke, Katila and Eisenhardt [23] showed that venture capital was the most successful source of funding in terms of the number of patents and FDA approvals received by supported firms. Samila and Sorenson [24] confirmed that the growth of the venture capital supply leads to an increase in company creation, employment and aggregate income. Puri and Zarutskie [25] found that VC-backed firms outperform their matched non-VC counterparts in terms of lower failure rates as well as IPO and acquisition rates.

While previous research demonstrated the positive impact of state programmes for supporting SMEs [26; 27], the influence of state institutions such as state venture funds on company performance was found to be ambiguous. For example, Luukkonen, Deschryvere and Bertoni [28] found no differences in contribution to portfolio companies between state venture capital (GVC) funds and independent venture capital (IVC) funds, while Grilli and Murtinu [29] showed that IVC funds positively impact the sales growth of high-tech firms, while GVC funds affect neither sales nor employee growth.

In addition, previous literature showed that the influence of state funding on entrepreneurship and innovation is dependent on the channel of such support. Fleming [30] provided evidence that the proportion of US patents relying on state funding reached $30 \%$ in 2011 , with start-ups being heavily dependent on state research.
This paper contributes to existing literature by examining the characteristics of start-ups supported from different sources using a sample of Russian biotech start-ups. As a country with limited private investments gives particular importance to state investments, this paper can contribute to the study of the capacity of state to fill institutional voids. Moreover, this is, as far as we know, the first study to describe the market of Russian biotech start-ups.

\section{Methodology}

In order to compare start-ups supported from different sources, our sample of Skolkovo participants in the biomed cluster in 2018 is divided into four clusters based on the presence of state and/or private support. We separate firms which do not get any support (besides being Skolkovo participants), firms which get significant state support, firms supported only by private companies and/or funds, and firms which are supported by both state and private institutions. Consequently, the clusters are based on the following variables: private company share (Russian and foreign), $\mathrm{PE} / \mathrm{VC}$ share, State institution share, residence in Skolkovo or other technoparks, presence of external financing and Skolkovo grant received by the start-up. During the first stage, the characteristics of the start-ups are examined to determine whether start-ups supported by the state are different from those supported by private institutions. In particular, we shall analyse age, ownership concentration, and experience and gender of start-up owners and CEOs.

During the second stage, the performance of start-ups from different clusters shall be compared. In particular, three main indicators are used to measure the performance of a start-up: the number of employees, the number of patents owned by the start-up, and the presence of a minimum viable product (MVP), which we proxy by the presence of company revenue.

As there are more than two clusters and the sample is classified by the type of support, the analysis of cluster characteristics shall be based on a comparison of mean values using a one-way analysis of variance (ANOVA). The null ANOVA hypothesis assumes the equality of in-cluster mean values against the alternative hypothesis of the existence of clusters with unequal means. If any significant differences are identified using ANOVA, we shall further examine which particular pair of group mean values show differences, taking the multiple comparison problem with the Bonferonni correction into account. As 6 pairwise comparisons are run, alpha must be equal to $5 \% / 6=0.83 \%$ for a $5 \%$ level of significance of the Bonferonni correction. Although the ANOVA test assumes normally distributed data, studies have shown moderate effects of non-normality on the Type 1 error $[31 ; 32]$; therefore, no transformation of the variables is made in this paper to fit the normality assumption. For binary variables, Pearson's chi-squared tests with the null hypothesis for the independence of the type of support and chosen characteristics will be performed.

It should be noted that this study is mainly descriptive in nature and that the proposed methodology does not aim 
to study the causal relationship between a start-up's characteristics, its type of support and its subsequent performance. However, the next step in this research would be to enlarge the sample to include Russian start-ups which are not participants of the Skolkovo ecosystem. Thereafter, start-ups which are residents of Skolkovo and start-ups supported by private investors should be compared using a methodology that would take the potential endogeneity of such support into account. Moreover, further research should also consider differences in channels of support from private and state investors.

\section{Data}

The list of biomed start-ups was collected from the Skolkovo website, and the description of each start-up was analysed to classify its activities. As of May 13, 2020, there were 510 start-ups in the Skolkovo biomedical cluster, with 119 companies in agriculture and industrial biotechnolo- gies and 391 medtech companies. Out of 119 companies working in agriculture and industrial biotechnologies, 38 were engaged in plant breeding, 29 in animal breeding, 46 focused on various industrial biotechnologies and 6 were foodtech companies.

Of the 391 medtech companies, the majority (139) specialized in drug manufacturing with 37 focusing on oncological diseases, 24 on infectious/viral/parasitic diseases and 13 on degenerative diseases. Other fields of specialization of medtech start-ups included the production of medical instruments/equipment/materials (77 firms), IT solutions (55), diagnostic methods (53), genomics (21) and other equipment for daily life (6).

Most Skolkovo biomed start-ups are located in Moscow, Saint Petersburg and the Moscow Oblast (Figure 2). The other regions with the greatest number of start-ups (Novosibirsk Oblast, Nizhny Novgorod Oblast, Tomsk Oblast, and Tatarstan) are known for their research institutes and universities.

Figure 2. Location of Skolkovo biomedical start-ups

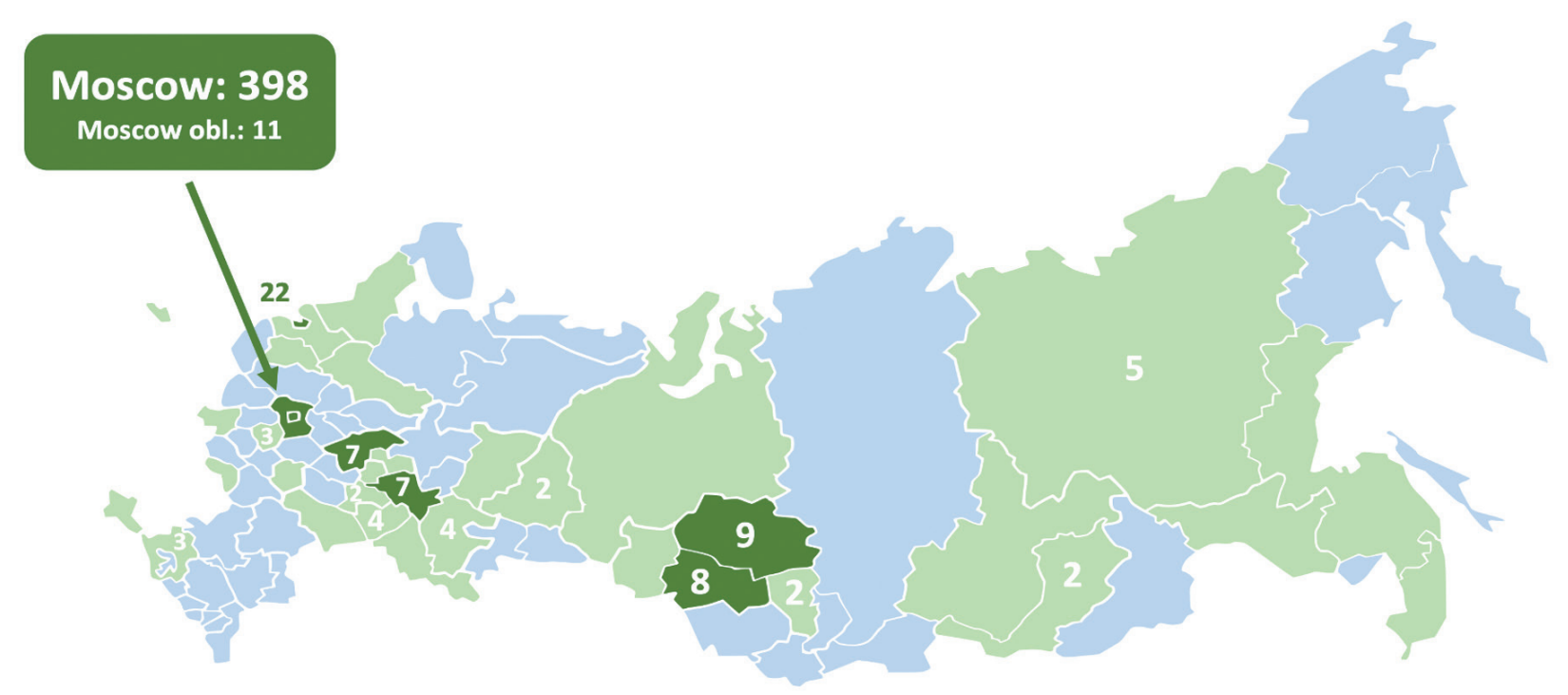

${ }^{\star}$ Regions without Skolkovo biomedical start-ups are shaded in light blue, while regions with 1 Skolkovo biomed start-up are shaded in light green without a number.

Source: Skolkovo website, author's representation.

Skolkovo regulations do not have a strict age limit for startups, and the oldest company in the sample is 30 years old. However, the median company age in the data sample was 4 years, which indicates that $50 \%$ of the companies were founded in 2016 and later (Figure 3).

Data for the number of company employees is presented by Spark Interfax for only 391 companies. Most start-ups satisfy the generally accepted criteria for small and micro enterprises set by the European Commission and the Russian Small and Medium Business Corporation; however, there are 7 firms with more than 50 employees (Figure 4). The median staff headcount of the biomedical start-ups in the sample is 3 . 
Figure 3. Age distribution of biomedical start-ups, May 2020

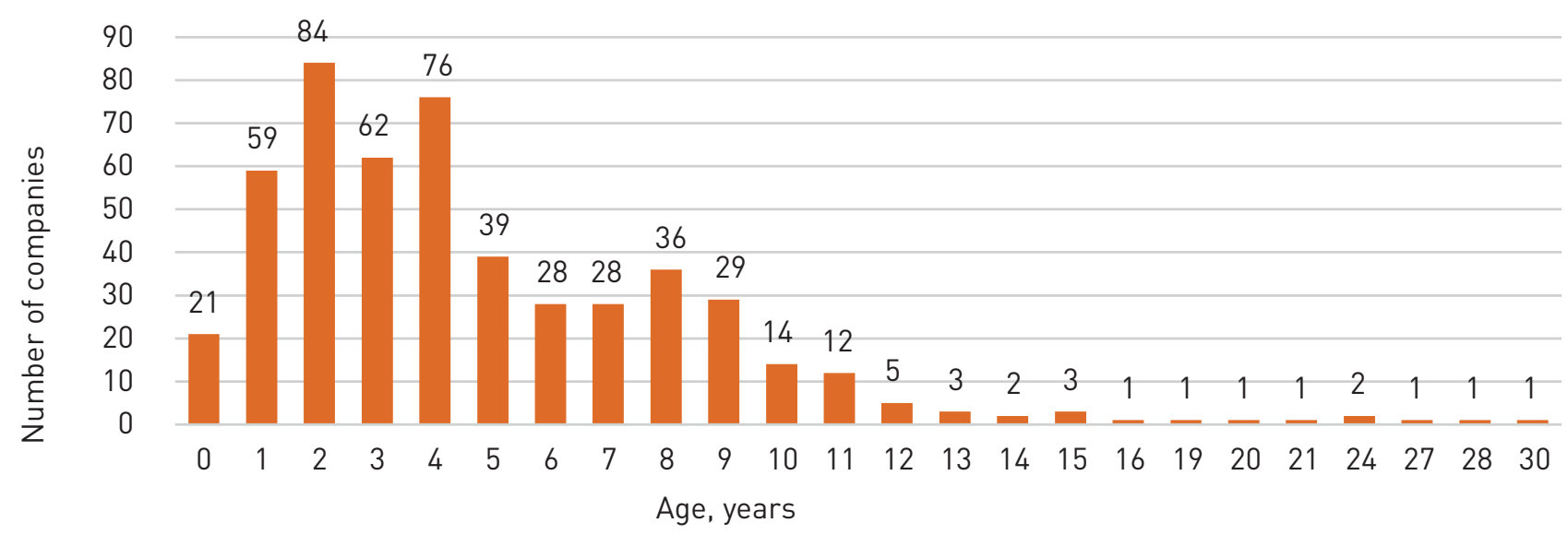

Source: Spark Interfax, author's representation.

Figure 4. Distribution of the number of employees in biomed start-ups, May 2020

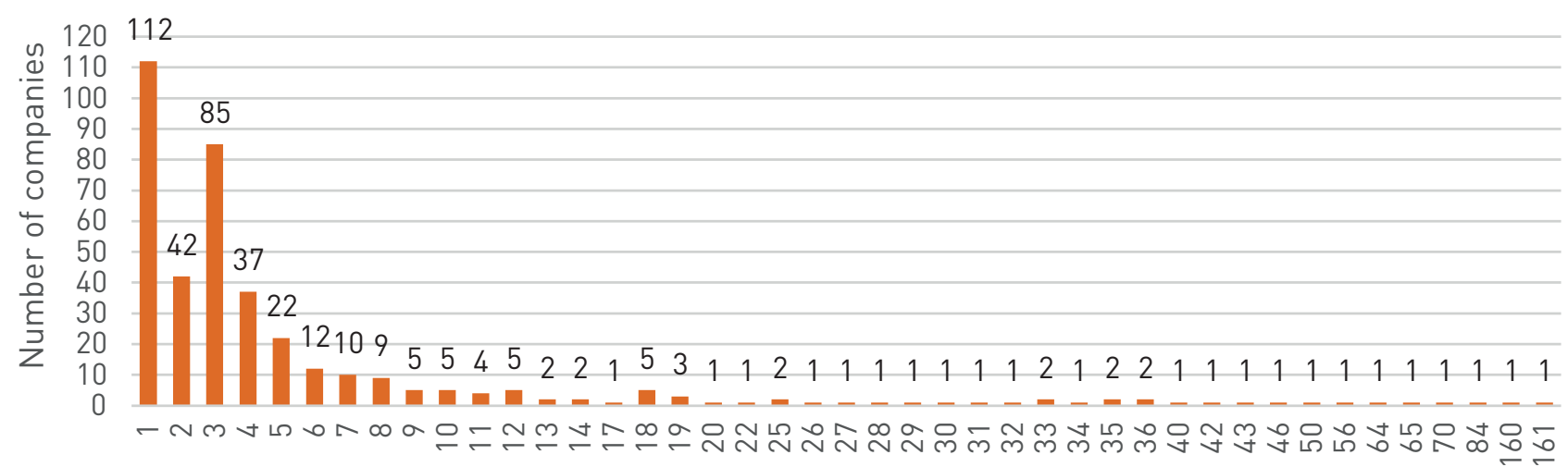

Number of employees

Source: Spark Interfax, author's representation.

When we were working on this study, no information was available about the 2019 financial results of companies, and so we used 2018 financial data. Thus, all startup characteristics are presented as of late 2018. Our final data sample consists of 213 Skolkovo start-ups from the biomedical cluster, which most recently became Skolkovo participants (as of the end of 2018). While 50\% (median group) of the 213 start-ups in our sample were established after 2017, two companies were established in 1993 and 1995, four companies in 2000, 2004, 2006 and 2007, and the rest after 2008. The number of owners in the median biomedical start-up was 2 , while the average biggest share of ownership in a start-up was $67.2 \%$ (Table 1).

At least $70 \%$ of the start-ups in the sample had managerial ownership in their ownership structure, with an average CEO share of $53.2 \%$. $72 \%$ of owners of the start-ups in the sample had ownership in other companies earlier, while
$59 \%$ of the CEOs of biomedical companies in the sample had previous CEO experience. A significant positive correlation was also found between an experienced owner and an experienced CEO in a start-up (Table 4).

Furthermore, start-ups from the 2018 biomedical cluster were compared with a sample of start-ups from the 2017 space and nuclear industry clusters, which had been studied by Guseva and Stepanova [33]. The descriptive statistics indicate that start-ups from the biomedical cluster are younger than start-ups from the nuclear and space clusters in Skolkovo (median age of 2 vs. 4 years), their ownership structure is less concentrated (median biggest share of $60 \%$ vs. $76 \%$ ), and the CEO has a higher share in the company (average CEO share of 53\% vs. $43 \%$ ). Moreover, biomedical start-ups are more gender diverse than start-ups from the nuclear and space clusters: the share of start-ups with female owners is two times higher (35\% vs. $15 \%)$, while female CEOs are four times more common. 
Table 1. Descriptive statistics of start-ups in the biomedical cluster in 2018

\begin{tabular}{|c|c|c|c|c|c|c|}
\hline & Count & Median & Min & Max & Mean & Std. dev. \\
\hline Age & 213 & 2 & 1 & 26 & 3.53 & 3.48 \\
\hline Number of owners & 213 & 2 & 1 & 12 & 2.46 & 1.52 \\
\hline \multirow[t]{2}{*}{ Biggest share, \% } & 213 & 60 & 16.67 & 100 & 67.21 & 25.22 \\
\hline & & \multicolumn{2}{|c|}{ \# of start-ups } & \multicolumn{3}{|c|}{$\%$ in total sample of 213 start-ups } \\
\hline \multicolumn{2}{|c|}{ CEO share $($ avg. share $=53.2 \%)$} & \multicolumn{2}{|l|}{149} & \multicolumn{2}{|c|}{70} & \\
\hline \multicolumn{2}{|l|}{ Experienced owner } & \multicolumn{2}{|l|}{154} & \multicolumn{2}{|c|}{72} & \\
\hline \multicolumn{2}{|l|}{ Experienced CEO } & \multicolumn{2}{|l|}{126} & \multicolumn{2}{|c|}{59} & \\
\hline \multicolumn{2}{|c|}{ Presence of female owner } & \multicolumn{2}{|l|}{74} & \multicolumn{2}{|c|}{35} & \\
\hline \multicolumn{2}{|l|}{ Female CEO } & \multicolumn{2}{|l|}{47} & \multicolumn{2}{|c|}{22} & \\
\hline
\end{tabular}

Table 2. Description of dependent variables

\begin{tabular}{|c|c|c|c|c|c|c|}
\hline & Count & Median & Min & $\operatorname{Max}$ & Mean & Std. dev. \\
\hline Number of team members & 207 & 4 & 2 & 5 & 3.65 & 0.60 \\
\hline Number of employees & 190 & 3 & 1 & 108 & 5.45 & 11.66 \\
\hline Assets, thousand RUB & 177 & 3087 & 2 & 1427587 & 50611 & 183151 \\
\hline Debt, thousand RUB & 178 & 1997 & 0 & 945113 & 24374 & 96682 \\
\hline Revenue, thousand RUB & 167 & 0 & 0 & 590857 & 14210 & 62481 \\
\hline Net profit, thousand RUB & 164 & -61 & -80634 & 275009 & 3466 & 28992 \\
\hline & \multicolumn{2}{|c|}{ \# of start-ups } & \multicolumn{4}{|c|}{$\%$ of total sample } \\
\hline MVP>0 & \multicolumn{2}{|c|}{71} & \multicolumn{3}{|c|}{33} & \\
\hline Patents $>0$ & \multicolumn{2}{|c|}{69} & \multicolumn{3}{|c|}{32} & \\
\hline
\end{tabular}

As performance measures we took the typical indicators used for start-ups in the academic literature: the number of employees, financial indicators [25] and the number of patents [23]. In our data sample, the median start-up had 4 team members (according to the Skolkovo webpages of the start-ups; team members usually exercise managerial functions such as $\mathrm{CFO}$ or COO) and 3 employees (Table 2). The average number of patents for a company was 1.01 , with only $32 \%$ of start-ups having one or more patents. We took the main financial indicator of start-up performance to be the presence of revenue (which we associate with the presence of a minimum viable product (MVP)). Only 33\% of start-ups in the sample had positive revenues (with the average revenue of such companies equal to RUB 33.4 million).

To differentiate between start-ups supported by state and private institutions, we looked at information about own- ership structure and sources of financing on the Skolkovo website. In addition, we checked whether the start-up was a resident of a technopark, which is considered to be a state-supported structure.

$19 \%$ of the start-ups in the sample were residents of the Skolkovo Technopark, and 13\% of other technoparks. 51\% of the start-ups in the sample received Skolkovo grants with an average grant amount of RUB 12 million. Data for binary variables indicating the presence of attracted external financing (which is considered private funding) was taken from the start-ups' Skolkovo webpages.

We traced the share of state venture funds (e.g. RVC), educational entities (e.g. MIFI) and state research institutes (e.g. NII KPSZ of the Kuzbass Cardiology Centre) in the ownership makeup of start-ups to determine the presence of state support. Only 6 start-ups (3\%) in the sample had this kind of support, while over $18 \%$ of start-ups in the nuclear and space 
clusters had state institutions in their ownership structure [33]. In addition, 5\% of start-ups in the nuclear and space clusters were at least partially owned by state companies such as Rostec and Roscosmos, while no state-controlled companies were observed in the ownership structure of our sample of 213 Skolkovo biomedical start-ups [33].

Table 3. Description of grouping factors
Among the private institutions supporting start-ups, we distinguished between Russian private companies, foreign companies, PE and VC funds, and business angels (Table 3). However, none of the 82 most active business angels (information about which is published by RVC) were found in the ownership structure of the start-ups.

$\begin{array}{llcl}\begin{array}{l}\text { Type of owner/ } \\ \text { characteristic }\end{array} & \begin{array}{l}\text { \# of start-ups with } \\ \text { this type of owner/ } \\ \text { characteristic }\end{array} & \begin{array}{l}\% \text { of sample of } 213 \\ \text { start-ups }\end{array} & 24\end{array}$

The correlation matrix (Table 4) also gives some insight into the relationship between different start-up characteristics.

The presence of state support in the form of technopark residence is positively and significantly correlated with the number of start-up patents, while a state share in the ownership of a start-up has a positive relation to the number of its employees. In addition, the presence of Skolkovo funding is positively correlated with the start-up's number of patents and presence of revenue (MVP).

We have not found any significant correlation between the presence of a private Russian or foreign company in the ownership structure or of external financing and the chosen indicators of start-up performance. However, the PE/ VC share was found to correlate positively and significantly with the presence of start-up revenue.

We also confirmed that private support in the form of private Russian or foreign company ownership was positively correlated with ownership concentration and negatively correlated with the CEO share. In addition, the chosen indicators of start-up performance had a positive and significant correlation inter se. 
Table 4. Correlation matrix

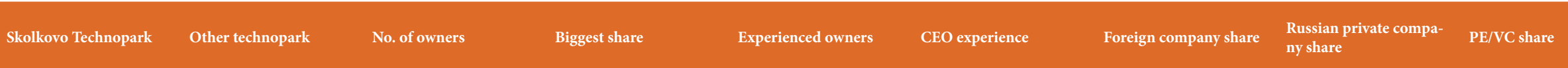

CFo share

State institution share $\quad$ No. of emplogeses

External funding

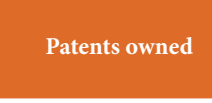

nvp

Skolkovo

$1.00^{* * *}$

0.05

0.11

$-0.02$

$0.08 \quad 0.00$

0.05

$-0.09 \quad 0.00$

$0.05 \quad 0.05 *$

$-0.01$

$-0.01$

\begin{tabular}{|c|c|c|c|c|c|c|c|c|c|c|c|c|c|c|c|c|c|}
\hline Dther technopark & -0.03 & -0.08 & $1.00^{* * *}$ & 0.06 & $-0.07^{\star *}$ & $0.12^{*}$ & 0.07 & -0.08 & -0.06 & -0.06 & 0.00 & 0.07 & $0.19^{* *}$ & 0.03 & 0.08 & $0.11^{*}$ & 0.02 \\
\hline No. of owners & 0.04 & 0.05 & 0.06 & $1.00^{* * *}$ & $-0.69 \times * *$ & $0.32^{* * *}$ & 0.09 & -0.02 & -0.04 & $0.21^{* *}$ & -0.34 & 0.06 & 0.09 & 0.10 & 0.04 & 0.12 & 0.15 \\
\hline Biggest share & 0.04 & -0.01 & $-0.07 * *$ & $-0.69^{* * *}$ & $1.00^{* * *}$ & $-0.39 * * *$ & -0.03 & $0.16^{* * *}$ & $0.14^{* * *}$ & $-0.15^{*}$ & 0.35 & -0.02 & -0.04 & -0.14 & -0.00 & 0.06 & -0.13 \\
\hline
\end{tabular}

Biggest share 0.04

$-0.02 \quad 0.16$

$\begin{array}{lll}-0.08 & 0.10 \quad 1.00\end{array}$

$-0.06 \quad-0.003$

share

$\begin{aligned} & \text { Russian private } \\ & \text { company share }\end{aligned}$
on

$\begin{array}{lll}\mathrm{E} / \mathrm{VC} \text { share } & 0.02 & 0.00\end{array}$

CEO share $\quad 0.04 * *$

$\begin{array}{lllll}-0.05 & 0.00 & -0.34 & 0.35 & -0.02\end{array}$

$\begin{array}{llll}\text { State institution } & 0.17 & -0.09 & 0.07\end{array}$

State institution
share

No. of employees $\quad 0.44^{* * *}$

Debt $\quad 0.50^{* * *} \quad-0.02 \quad 0.07$

$\begin{array}{lllll}0.12 & 0.07 & 0.13\end{array}$

\begin{tabular}{|c|c|c|c|c|}
\hline levenue & $0.34^{* * *}$ & -0.05 & 0.12 & 0.02 \\
\hline Net profit & 0.12 & -0.04 & -0.02 & -0.07 \\
\hline
\end{tabular}

External funding $0.00 \quad 0.05$

Patents owned $\quad 0.65^{* * *} \quad 0.05^{* *}$

xperienced

CEO experience 0.002

$\operatorname{MVP}-0.11$

Skolkovo funding $0.19^{* * * *}$

$1.00^{* * *}$

$-0.01+11^{*}-0.0120$

-0.07
-0.0

-0.03
0.02 


\section{Results and conclusion}

The clusterization of the data sample by private and state support yielded four clusters of start-ups. The first cluster ("no support") includes 32 companies for which the presence of state or private support was not confirmed. However, it should be said that, although no sources of support were identified by our methodology for such companies, they may still receive the support of friends, family, or employees. The second cluster ("state support") has 58 startups that are residents of a technopark and/or have Skolkovo grants and/or have a state institution share in their ownership structure yet do not receive any private support. The third cluster ("private support") includes 39 start-ups that do not have any state support besides being Skolkovo participants and have a private Russian or foreign or PE/VC fund in their ownership structure or have received external financing in the past. The fourth cluster ("mixed support") consists of 84 start-ups that receive both types of support.

The descriptive statistics of the four clusters are presented in Table 5. Companies which have both types of support tend to be older, which is a consistent conclusion: survival of a start-up is considered to be a positive sign by investors, while more support can increase the likelihood of the company's survival.
One-way ANOVA analysis indicated that there exist significant variations in the ownership concentration, managerial ownership and CEO experience among the four clusters. A multiple pairwise comparison of the number of owners and the biggest share in a start-up (Appendix 1) did not show any statistically significant differences between purely state and privately supported companies, while the ownership of companies with mixed support was significantly less concentrated. At the same time, a significant difference was observed in the CEO share: the highest share of CEO ownership was found in start-ups with no support at all or with state support. It was also shown that state-supported start-ups had more experienced CEO than companies financed by private institutions (Table 6).

In addition, the data indicate that start-ups which are founded, owned or managed by women are less likely to receive any type of support, which partially confirms the findings of Kwapisz and Hechavarría [34] that being a woman significantly lowers the probability of asking for funding. Pairwise comparisons (Appendix 2) show that the most significant difference in gender diversity was observed between start-ups with no support and start-ups with private support, while companies with state support are almost as much gender-diversified as firms with no support.

Table 5. Descriptive statistics of clusters

\begin{tabular}{|c|c|c|c|c|}
\hline Type of support & $\begin{array}{l}\text { Established } \\
\text { (median) }\end{array}$ & $\begin{array}{l}\text { Number of owners } \\
\text { (average) }\end{array}$ & $\begin{array}{l}\text { Biggest share (av- } \\
\text { erage), } \%\end{array}$ & $\begin{array}{l}\text { CEO share } \\
\text { (average), } \%\end{array}$ \\
\hline No support & 2017 & 1.81 & 72.39 & 58.12 \\
\hline State & 2016.5 & 2.33 & 66.98 & 55.25 \\
\hline Private & 2017 & 2.13 & 73.89 & 34.74 \\
\hline Mixed & 2016 & 2.94 & 62.28 & 27.84 \\
\hline F-stat & & 5.8653 & 2.4838 & 11.3044 \\
\hline $\mathrm{p}$-value & & 0.0007 & 0.0618 & 0.0000 \\
\hline
\end{tabular}

Table 6. Descriptive statistics of clusters (proportion of such companies in the cluster), \%

\begin{tabular}{|c|c|c|c|c|c|}
\hline $\begin{array}{l}\text { Type of sup- } \\
\text { port }\end{array}$ & $\begin{array}{l}\text { Ownership } \\
\text { experience }\end{array}$ & $\begin{array}{l}\text { CEO experi- } \\
\text { ence }\end{array}$ & Female founder & Female owner & Female CEO \\
\hline No support & 78 & 41 & 47 & 47 & 34 \\
\hline State & 74 & 66 & 38 & 40 & 28 \\
\hline Private & 64 & 49 & 26 & 21 & 10 \\
\hline Mixed & 73 & 67 & 23 & 32 & 19 \\
\hline Chi-2 & 1.9529 & 9.2391 & 8.3569 & 6.4491 & 7.4550 \\
\hline $\mathrm{p}$-value & 0.5822 & 0.0263 & 0.0392 & 0.0917 & 0.0587 \\
\hline
\end{tabular}


Our findings about start-up performance indicate that start-ups which are supported from both private and state sources tend to be bigger and more successful: on average, such start-ups have a higher number of employees and more patents and are more likely to have revenue (MVP). At the same time, support from private institutions is more often observed among start-ups which are smaller in terms of asset size, number of employees, number of patents and revenue. However, the significance of performance differences between clusters was not confirmed.
Companies with state support have a smaller average debt than start-ups from other clusters, which may indicate that equity and grant financing are more popular kinds of support for such institutions. At the same time, start-ups from the sample with no support have more debt, which indicates that the clusterization of companies can be improved by accounting for debt sources. While the source of debt is confidential information and cannot be traced using publicly available data, the information about attracted external financing from the Skolkovo website, which is included in the analysis, partially reflects the debt of start-ups.

Table 7. Performance of start-ups in different clusters

\begin{tabular}{|c|c|c|c|c|}
\hline Type of support & MVP (\% in cluster) & Assets (average) & Debt (average) & Revenue (average) \\
\hline No support & 69 & 29159.67 & 6987.86 & 4026.37 \\
\hline State & 59 & 40347.85 & 17817.29 & 14613.51 \\
\hline Private & 41 & 7793.47 & 4396.31 & 6484.22 \\
\hline Mixed & 52 & 80520.33 & 41505.53 & 12848.34 \\
\hline F-stat & $6.0241^{\star}$ & 1.4228 & 1.5765 & 0.3567 \\
\hline p-value & 0.1104 & 0.2378 & 0.1968 & 0.7842 \\
\hline
\end{tabular}

${ }^{*}$ Chi-2 is given.

\begin{tabular}{|c|c|c|c|}
\hline Type of support & $\begin{array}{l}\text { Number of employees } \\
\text { (average) }\end{array}$ & $\begin{array}{l}\text { Number of patents } \\
\text { (average) }\end{array}$ & $\begin{array}{l}\text { Number of patents ac- } \\
\text { quired in } 2018 \text { (average) }\end{array}$ \\
\hline No support & 4.93 & 0.56 & 0.13 \\
\hline State & 5.94 & 1.10 & 0.33 \\
\hline Private & 2.36 & 0.64 & 0.10 \\
\hline Mixed & 6.82 & 1.39 & 0.32 \\
\hline F-stat & 1.1322 & 0.8441 & 1.0778 \\
\hline $\mathrm{p}$-value & 0.3374 & 0.4712 & 0.3595 \\
\hline
\end{tabular}

Observations about the characteristics and performance of start-ups supported from different sources also indicate that the source of support for biomed start-ups can depend on the life-cycle stage of the company. In this paper, "startup" is generally defined in line with Skolkovo regulations yet also includes companies at their seed stage as well as companies which have started their international expansion and are generating sustainable revenue.

In our sample of start-ups, support from private investors was more often observed for younger companies whose performance (measured by the presence of revenue, assets, and the number of employees and patents) was leaner than firms from other clusters. This partially confirms the findings of Puri and Zaratuskie [25], who corroborated the claim that venture capitalists are willing to invest in com- panies with no immediate revenue. At the same time, state support is observed for more mature companies, which may also indicate that the support provided by private and state institutions is different in nature: while private organisations more often provide companies in this sample with guidance at early stages (initial customer expansion), state institutions can patronage regulatory approvals and hurdling of administrative barriers, as well as giving access to state contracts and networks. However, the most successful start-ups in this sample were supported by both state and private organisations, which partially confirms the findings of Cumming, Grilli and Matrinu [35] that mixed syndicated investments of independent and state venture funds have a positive effect on the exit performance of tech start-ups. 
While this paper is one of the first studies of biotech startups in Russia and has a descriptive purpose, further research should examine the causal relationships between start-up characteristics, the type of support, and start-up performance to identify which type of support should be provided to a particular start-up to maximize its performance. Moreover, the specificity of biotech companies requires further and deeper investigation of the various channels of support that can be used by such companies and that may differ from other tech-industries.

Our results indicate that, although the state is an important source of support for start-ups on emerging markets, it cannot be considered to be an absolute substitute for private investments and expertise. In addition, we should point out that state and private investors may be interested in different kinds of start-ups due to different goals: while private investors are looking for investments with the highest returns, state institutions are more focused on the longterm social effects of their investments, which is especially important for start-ups in the biomed industry. Therefore, the synergy of these sources can be an important driver for biomedical start-up performance.

\section{References}

1. International Monetary Fund. World Economic Outlook Update, June 2020. Available from: https://www.imf.org/en/Publications/WEO/ Issues/2020/06/24/WEOUpdateJune2020

2. Kuchler H., Mooney A. Pharma industry seizes on pandemic as a shot at redemption. Financial Times. 2020 Jul 5.

3. Manuilova A. Drug market grew on virus (Рынок лекарств вырос на вирусе). Kommersant. 2020 Jun 18.

4. Kravchenko E. Which Russian industries were hit most by coronavirus pandemic (Какие отрасли российской промышленности пострадали от пандемии коронавируса сильнее всего). Forbes. 2020 Jul 1.

5. Russian Venture Capital Association. Private equity and venture capital investments market review in 2018 (Обзор рынка прямых и венчурных инвестиций за 2018 год). Available from: http://www. rvca.ru/rus/resource/library/rvca-yearbook/

6. KPMG. Venture Pulse: Q4'18 Global analysis of venture funding. Available from: https://assets.kpmg/ content/dam/kpmg/xx/pdf/2019/01/kpmg-venturepulse-q4-2018.pdf

7. Lazonick W, Tulum Ö. US biopharmaceutical finance and the sustainability of the biotech business model. Research Policy. 2011; 40(9):1170-1187.

8. Dua A, Mahajan D, Oyer L, Ramaswamy S. US small-business recovery after the COVID-19 crisis. McKinseyeCompany. 2020 Jul 7.
9. Thurik R, Wennekers S. Entrepreneurship, small business and economic growth. Journal of Small Business and Enterprise Development. 2004; Vol. 11 No. 1: pp. 140-149.

10. Van Stel A, Carree M, Thurik R. The effect of entrepreneurial activity on national economic growth. Small business economics. 2005; 24(3): 311 321.

11. Acs Z J, Estrin S, Mickiewicz T, Szerb L. Entrepreneurship, institutional economics, and economic growth: an ecosystem perspective. Small Business Economics. 2018; 51(2): 501-514.

12. Portincaso M, de la Tour A, Soussan P. The Dawn of the Deep Tech Ecosystem. BCG.com. 2019 Mar 14. Avaliable from: https://www.bcg.com/ publications/2019/dawn-deep-tech-ecosystem.aspx

13. Dsight. Venture Russia. 2018 results (Венчурная Россия. Результаты 2018 года). Available from: http://dsight.ru/company/news/Исследование\%20 Dsight\%20Венчурная\%20Россия\%20-\%20 итоги\%202018\%20года.pdf

14. Nosella A, Petroni G, Verbano C. How Do Italian Biotech Startups Survive? Journal of Business Chemistry. 2006; Vol. 3, No. 2.

15. Schwienbacher A. A theoretical analysis of optimal financing strategies for different types of capitalconstrained entrepreneurs. Journal of Business Venturing. 2007; 22 (6): 753-781.

16. Drover W, Wood M, Fassin Y. Take the money or run? Investors' ethical reputation and entrepreneurs' willingness to partner. Journal of Business Venturing. 2014; 29(6): 723-740.

17. Islam M, Fremeth A, Marcus A. Signaling by Early Stage Startups: US Government Research Grants and Venture Capital Funding. Journal of Business Venturing. 2018; 33(1): 35 - 51.

18. Knockaert M, Clarysse B, Wright M. The extent and nature of heterogeneity of venture capital selection behaviour in new technology-based firms. R\&D Management. 2010; 40: 357-371.

19. Malmström M, Voitkane A, Johansson J, Wincent J. What do they think and what do they say? Gender bias, entrepreneurial attitude in writing and venture capitalists' funding decisions. Journal of Business Venturing Insights, 2020; 13.

20. Shane S, Cable D. Network Ties, Reputation, and the Financing of New Ventures. Management Science. 2002; 48(3): 364-381.

21. Afful-Dadzie E, Afful-Dadzie A. A decision making model for selecting start-up businesses in a government venture capital scheme. Management Decision. 2016; Vol. 54 No. 3. 
22. Uzuegbunam I, Liao Y, Pittaway L, Jolley G. Human capital, intellectual capital, and government venture capital. Journal of Entrepreneurship and Public Policy. 2017; Vol. 6 No. 3: 359-374.

23. Pahnke E, Katila R, Eisenhardt K. Who Takes You to the Dance? How Partners' Institutional Logics Influence Innovation in Young Firms. Administrative Science Quarterly. 2015; 60(4): 596-633.

24. Samila S, and Sorenson O. Venture Capital, Entrepreneurship, and Economic Growth. The Review of Economics and Statistics. 2011; 93 (1): 338-349.

25. Puri M, Zarutskie R. On the Life Cycle Dynamics of Venture-Capital- and Non-Venture-Capital-Financed Firms. Journal of Finance. 2012; 67 (6): 2247-2293

26. Doh S, Kim B. Government support for SME innovations in the regional industries: The case of government financial support program in South Korea. Research Policy. 2014; 43(9): 1557-1569.

27. Keller M, Block F. Explaining the transformation in the US innovation system: the impact of a small government program. Socio-Economic Review. 2012; 11(4): 629-656.

28. Luukkonen T, Deschryvere M, Bertoni F. The value added by government venture capital funds compared with independent venture capital funds. Technovation. 2013; 33(4-5): 154-162.

29. Grilli L, Murtinu S. Government, venture capital and the growth of European high-tech entrepreneurial firms. Research Policy. 2014; 43(9): 1523-1543.

30. Fleming L, Greene H, Li G, Marx M, Yao D. Government-funded research increasingly fuels innovation. Science. 2019; 364(6446): 1139.

31. Harwell M R, Rubinstein E N, Hayes W S, Olds C C. Summarizing Monte Carlo results in methodological research: The one-and two-factor fixed effects ANOVA cases. Journal of educational statistics. 1992; 17(4): 315-339.

32. Lix L M, Keselman J C, Keselman H J. Consequences of assumption violations revisited: A quantitative review of alternatives to the one-way analysis of variance F test. Review of educational research. 1996; 66(4): 579-619.

33. Guseva O, Stepanova A. Owners and CEOs of Startups: Evidence from Russia. Journal of Corporate Finance Research/Корпоративные Финансы. 2019; 13(1): 107-119.

34. Kwapisz A, Hechavarría D M. Women don't ask: an investigation of start-up financing and gender. Venture Capital. 2018; 20(2): 159-190.

35. Cumming D J, Grilli L, Murtinu S. Governmental and independent venture capital investments in Europe: A firm-level performance analysis. Journal of corporate finance. 2017; 42: 439-459. 


\section{Appendix 1. Pairwise comparisons (Bonferroni-adjusted alpha equal to $5 \% / 6=0.83 \%$ )}

\section{1a. Number of owners}

\begin{tabular}{|c|c|c|c|c|c|c|}
\hline Cluster 1 & Cluster 2 & $\begin{array}{l}\text { Mean } \\
\text { cluster } 1\end{array}$ & $\begin{array}{l}\text { Mean } \\
\text { cluster } 2\end{array}$ & t-stat & $\begin{array}{l}t \text { critical } \\
\text { two-tail }\end{array}$ & p-value \\
\hline No support & State & 1.81 & 2.33 & -2.3340 & 1.9873 & 0.0219 \\
\hline No support & Private & 1.81 & 2.13 & -1.3981 & 1.9971 & 0.1668 \\
\hline No support & Mixed & 1.81 & 2.94 & -4.7133 & 1.9810 & 0.0000 \\
\hline State & Private & 2.33 & 2.13 & 0.7780 & 1.9867 & 0.4386 \\
\hline State & Mixed & 2.33 & 2.94 & -2.2848 & 1.9772 & 0.0238 \\
\hline Private & Mixed & 2.13 & 2.94 & -2.9811 & 1.9818 & 0.0035 \\
\hline
\end{tabular}

\section{1b. Biggest share}

\begin{tabular}{|c|c|c|c|c|c|c|}
\hline Cluster 1 & Cluster 2 & $\begin{array}{l}\text { Mean } \\
\text { cluster } 1\end{array}$ & $\begin{array}{l}\text { Mean } \\
\text { cluster } 2\end{array}$ & t-stat & $\begin{array}{l}t \text { critical } \\
\text { two-tail }\end{array}$ & p-value \\
\hline No support & State & 72.39 & 66.98 & 0.9675 & 1.9949 & 0.3367 \\
\hline No support & Private & 72.39 & 73.89 & -0.2575 & 1.9966 & 0.7976 \\
\hline No support & Mixed & 72.39 & 62.28 & 1.9987 & 2.0040 & 0.0506 \\
\hline State & Private & 66.98 & 73.89 & -1.3076 & 1.9879 & 0.1945 \\
\hline State & Mixed & 66.98 & 62.28 & 1.0716 & 1.9812 & 0.2862 \\
\hline Private & Mixed & 73.89 & 62.28 & 2.4589 & 1.9935 & 0.0163 \\
\hline
\end{tabular}

\section{1c. CEO share}

\begin{tabular}{|c|c|c|c|c|c|c|}
\hline Cluster 1 & Cluster 2 & $\begin{array}{l}\text { Mean } \\
\text { cluster } 1\end{array}$ & $\begin{array}{l}\text { Mean } \\
\text { cluster } 2\end{array}$ & t-stat & $\begin{array}{l}t \text { critical } \\
\text { two-tail }\end{array}$ & p-value \\
\hline No support & State & 58.12 & 55.25 & 0.3796 & 1.9983 & 0.7056 \\
\hline No support & Private & 58.12 & 34.74 & 2.7386 & 1.9955 & 0.0079 \\
\hline No support & Mixed & 58.12 & 27.84 & 4.3635 & 2.0086 & 0.0001 \\
\hline State & Private & 55.25 & 34.74 & 2.7626 & 1.9917 & 0.0072 \\
\hline State & Mixed & 55.25 & 27.84 & 4.9720 & 1.9812 & 0.0000 \\
\hline Private & Mixed & 34.74 & 27.84 & 1.0149 & 1.9990 & 0.3141 \\
\hline
\end{tabular}




\section{Appendix 2. Pairwise comparisons (Bonferroni-adjusted alpha equal to $5 \% / 6=0,83 \%$ )}

\section{2a. CEO experience}

\begin{tabular}{|c|c|c|c|c|c|}
\hline Cluster 1 & Cluster 2 & $\begin{array}{l}\text { Proportion } \\
\text { in cluster 1, } \%\end{array}$ & $\begin{array}{l}\text { Proportion } \\
\text { in cluster 2, \% }\end{array}$ & Chi-2 stat & p-value \\
\hline No support & State & 41 & 66 & 4.2394 & 0.0263 \\
\hline No support & Private & 41 & 49 & 0.1956 & 0.6583 \\
\hline No support & Mixed & 41 & 67 & 5.4847 & 0.0192 \\
\hline State & Private & 66 & 49 & 2.0669 & 0.1505 \\
\hline State & Mixed & 66 & 67 & 0.0015 & 0.9696 \\
\hline Private & Mixed & 49 & 67 & 2.8910 & 0.0891 \\
\hline
\end{tabular}

\section{2b. Female founder}

\begin{tabular}{|c|c|c|c|c|c|}
\hline Cluster 1 & Cluster 2 & $\begin{array}{l}\text { Proportion } \\
\text { in cluster } 1, \%\end{array}$ & $\begin{array}{l}\text { Proportion } \\
\text { in cluster 2, \% }\end{array}$ & Chi-2 stat & p-value \\
\hline No support & State & 47 & 38 & 0.3620 & 0.5474 \\
\hline No support & Private & 47 & 26 & 2.6056 & 0.1065 \\
\hline No support & Mixed & 47 & 23 & 5.4615 & 0.0194 \\
\hline State & Private & 38 & 26 & 1.0859 & 0.2974 \\
\hline State & Mixed & 38 & 23 & 3.2069 & 0.0733 \\
\hline Private & Mixed & 26 & 23 & 0.0194 & 0.8893 \\
\hline
\end{tabular}

\section{2c. Female CEO}

\begin{tabular}{|c|c|c|c|c|c|}
\hline Cluster 1 & Cluster 2 & $\begin{array}{l}\text { Proportion } \\
\text { in cluster } 1, \%\end{array}$ & $\begin{array}{l}\text { Proportion } \\
\text { in cluster } 2, \%\end{array}$ & Chi-2 stat & p-value \\
\hline No support & State & 34 & 28 & 0.1870 & 0.6654 \\
\hline No support & Private & 34 & 10 & 4.7741 & 0.0289 \\
\hline No support & Mixed & 34 & 19 & 2.2505 & 0.1336 \\
\hline State & Private & 28 & 10 & 3.2856 & 0.0699 \\
\hline State & Mixed & 28 & 19 & 0.9856 & 0.3208 \\
\hline Private & Mixed & 10 & 19 & 0.9350 & 0.3336 \\
\hline
\end{tabular}

